JURNAL BASICEDU

Research \& Learning in Elementary Education

https://jbasic.org/index.php/basicedu

\title{
APPLICATION OF MATH REVIEW GAME TO INCREASE COGNITIVE LEARNING OUTCOMES AND STUDENTS INVOLVEMENT LEVEL IN MATHEMATIC LESSON
}

\author{
Di Ohanes Richi Christian Plenden¹, Gamaliel Septian Airlanda ${ }^{2}$
}

Universitas Kristen Satya Wacana, Jawa Tengah, Indonesia ${ }^{1,2}$

Email292015104@student.uksw.edu¹, Gamaliel.septian@uksw.edu² ,

\begin{abstract}
Abstrak
Penelitian ini bertujuan untuk meningkatkan hasil belajar kognitif dan keaktifan murid kelas lima Mountainview Christian Elementary School dengan menerapkan model pembelajaran active learning dengan metode review game. Jenis penelitian yang dilakukan adalah penelitian tindakan kelas yang terdiri dari dua siklus. Data yang diperoleh berasal dari observasi, kuisioner, dan tes yang kemudian dianalisis dalam bentuk persentase. Data tes hasil belajar murid dianalisis berdasarkan persentase ketuntasan belajar secara individu dan klasikal. Hasil penelitian menunjukan hasil belajar murid dengan ketuntasan belajar klasikal mengalami peningkatan. Pada siklus pertama persentase ketuntasan belajar sebesar $85 \%$ mengalami peningkatan pada siklus kedua menjadi $100 \%$, rata-rata hasil belajar pada siklus pertama yaitu 9.23 meningkat di siklus kedua menjadi 9.73. Peningkatan hasil belajar juga diikuti dengan peningkatan hasil keaktifan siswa sebesar $15 \%$ dari siklus pertama sebesar 54\% dengan kategori cukup aktif menjadi 77\% di siklus kedua.dengan kategori aktif. Dari hasil Penelitian ini dapat disimpulkan bahwa penerapan model pembelajaran active learning dengan metode review game dapat meningkatkan hasil belajar kognitif dan keaktifan.
\end{abstract}

Kata Kunci: hasil belajar kognitif, keaktifan, review game.

\begin{abstract}
The purpose of this research is to increase cognitive learning outcomes and involvement level for fifth grade students of Mountainview Christian Elementary School with applying active learning and review game method. The research method that been used is Classroom Action Research which has two cycle. Data in this research gotten from observation, questionnaire, and test then analyzed in percentage form. Learning outcomes result analyzed based on the minimum completeness criteria percentage whether individual or general. The result of the research show that the student learning outcomes result in general increased. In the first cycle the students that pass the minimum completeness criteria was $85 \%$ and increased in the second cycle become $100 \%$, the learning outcomes average in the first cycle is 9.23 increased in the second cycle become 9.73. learning outcomes that increased also followed by the increasing of student involvement level about $15 \%$ from the first cycle which is $54 \%$ categorized as enough become $77 \%$ in the second cycle categorized as active. From this research result concluded that the applying of active learning with review game could increasing cognitive learning outcomes and involvement level of the students.
\end{abstract}

Keywords: learning outcomes, involvement level, review game

@ Jurnal Basicedu Prodi PGSD FIP UPTT 2019

$\triangle$ Corresponding author :

Address : Jalan Potrobangsan 1 no 193, Magelang

Email : 292015104@student.uksw.edu

Phone : 081328135840

ISSN 2580-3735 (Media Cetak)

ISSN 2580-1147 (Media Online) 


\section{Application Of Math Review Game to Increase Cognitive Learning Outcomes And Students Involvement Level In Mathematic Lesson- Di Ohanes Richi Christian Plenden, Gamaliel Septian Airlanda}

\section{INTRODUCTION}

Mathematic is an art, mathematic provide problem which have many ways to solve the problem according to the fixers character. Math is not strict, math can be flow and fun, math is not about memorizing, math is understanding the basic so we can create our own formula and solve the problem. According to Mc Clintock (1982), he says that problem solving is one kind of form of mental activity that has creative characteristic and requiring of ingenuity in conceptions or reflection. Mc Clintock (1982) also have opinions that the presentation of problems in math learning process has potential to motivate and excite reluctant for the students. This showed us that in teaching and learning math we need to make it fun and active, because that is the purpose of learning math, developing their knowledge and motivate them and excite them.

In teaching and learning process, a successful learning is an active and fun learning. According to Tony Stockwell in Dryden \& Vos (1999) says that we can learn something fast and effectifely if we expireinced it. So, if we have positive emulsion or an active and fun experience, then learning will be easier to understand and difficult to be gone or forgotten, also what we already learn become one with our experience.

By doing active learning, the understanding level of the student will be increased because they did and experienced it by themselves. If their understanding level about the lesson increase, then their learning outcomes will be increased too. According to the research from Johnson, Johnson, \& Smith (1991) show higher learning outcomes, and creating an health phsycology environment also good relationship between student as a result of active learning. Furthermore, Dewey (1938) says that individual and social experience or collaboration that be done with someone else is an important thing in teaching and learning process . Dewey puts in the first place about education is a social process which is need someone else and later on in our life, we will more need someone else, so this is why Dewey said that this is the important thing.

Active Learning is learning system which put the student involvement of every students with others in the first place, so learning is no more a competition. Bloom (1956) also writes in his book that education is a tool to reach the goals and not a competition, also need a diversity recognition to get through it. That's why in order to make education as a tool to reach the goal, Bloom made a taxonomy that we already known as Bloom's taxonomy. From bloom's taxonomy seen almost every step or level need an active learning to get through it. For example, in the third step of Bloom's taxonomy is application, we need the student's involved to applicate what they already learned, could be in individually, but the best way to deal with it is as a group. Also for the fourth, fifth, and sixth level, if the learning system is not an active learning, then the goal which is to make education as a tool to reach the goal will not accomplished.

Then, how we make a learning which prioritize student empiric experience or active learning. We need to prioritize student in the teaching learning, we could use student-centered model which focus on student. Dale (1969) share a cone of the process level to clarify the relationship between the learning level with active learning that focused on student.

From Edgar dale's cone, the conclusion is with "doing the real thing" and "simulating the real thing" or in other words by experiencing it directly, students will understand completely what they have learned. Students learn and when the students experience it directly in the active 


\section{Application Of Math Review Game to Increase Cognitive Learning Outcomes And Students Involvement Level In Mathematic Lesson- Di Ohanes Richi Christian Plenden, Gamaliel Septian Airlanda}

learning then students will learn more effectively than memorizing every single formula that they heard but not match with problem in the real life.

By interview and observation result that taken from Mountainview Christian Elementary School especially for fifth and sixth grade, students need an active learning. In this era, welcoming the revolution of education, students will be required for fast and full. In the lesson the students will be required to be faster in understanding the chapter in every lesson and also student could applicate it according to the highest level of Bloom's taxonomy, so this school especially for fifth and sixth grade need efficient way to be applied in the lesson. Students already know how to work in team but just focus in doing the task or homework. The teaching and learning process will be more efficient in understanding if there is a review game based on the material of what they have already learned and students active in the learning process or experiencing what they learned. So, student will quickly understand about the lesson and the material can be teach efficiently.

That is why this research elaborate math review game that will make the students more active and happy in the lesson. So, they will easily understanding and applying the lesson they have learned. With this model of learning, it will increasing efficiency. This is one kind of revolution of education which is needed by this school. According to Kline (1823) learning will be effective if its done in fun ways. Dryden \& Vos (1999) in their book The Learning Revolution said that in the New Zealand they have program called "Beginning School Mathematics", In this program they will use many kind of word puzzles and games that have rich color to learn about math basic connection. Teachers in New Zealand claimed that this learning model related to the growing schedule of Piaget, and showing better learning outcomescan be reached by many practical exercises. Darmansyah (2010) explaining that the result of his research in teaching and learning process in this last decade showing that learning will be more effective when the student in happy situation, it has been approve by given great effect to the students learning outcomes. Another survey from Hart in Darmansyah (2010) said that there are ten of teacher's character which hated by their students and the main point of it is when the teachers are not fun at all. When the human's brain get stimulation which is not fun or bored, big possibility that human's brain will give against reaction and constrict the memory to get the information that they get.

According to Goleman in DePorter, Mark Reardon, \& Sarah Singer-Nourie (2001) say that when the human's brain accepted a threat or pressure, nerve's capacity to think rationally will be shrink because the brain hijacked emotionally. Mihaly Csikszentmihalyi (1990) explain that with pressure or positive emultion will make brain in the "flow" situation, which is situation where someone furtherly involved in the activities so another activities as if nothing mattered anymore. It signed that if learning can be active and fun then learning will give positive emultion so can be easily remembered in student's brain, so with this method of review the lesson using game is something that usefull in this point in make the lesson more efficient. In the Indonesian Government Regulations Number 19 year 2005 about National Education Satndard in the chapter 19 verse 1 declare that: "learning process in educations unit held interactively, inspiratively, fun, challenging, and motivated the student to actively participate, give a space to move to be initiative, creativity and independency according to the talent, interest and physical development also student's psychology". 
According to Silver, Brunsting, \& Walsh (2012) there are 4 steps in math review game which is 1) Decide how much time, goals, and what time 2) Select game that meet the objectives 3) Provide clear direction 4) Allow the students to review the games/the material.

\section{METHODS}

This research use Classroom Action Research (CAR). This research purposed for knowing how far is the effect of present, and after applying the Math Review Game Method to the students, and what action need to do further. This research using Kemmis and MC Taggart (Kunandar, 2012). This classroom action research conducted by two cycles. Every cycles have four steps which are: plan, implementation, observation and reflection.

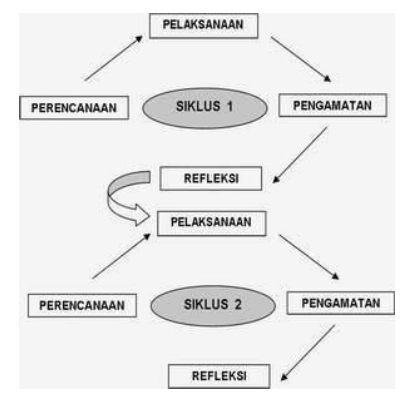

Figure 1. Kemmis and Taggart Model

The purpose of this research is to increasing the cognitive learning outcomes and involvement level of fifth grade students Mountainview Christian Elementary School. There are 5 boys and 8 girls, most of boys in this class is fast thinker and easy to be bored, that's why they usually play something after they done with their job. The opposite, girls in this class calmer and more paid attention, some of them are slow learners, some of them also fast thinker, but almost all of them not talking too much. One biggest problem in this class is most of them not fluent in
English, but they could understand if they see numbers. The characteristic of this class is they need to be more active because they already used to work in group but they just sharing for the answer not working through the way to solve the problem, this also make the learning outcomes of some students become bad and need to be increased. I used Active Learning with Math review game as the method of learning from the beginning to the end. Collecting data technique that been used is observation and test. Test and observation technique that been used in this research is a result of cognitive learning outcomes and involvement level of the students. Analysis data technique that been used is using instrument such as: student and teacher observation sheet, student involvement level questionnaire, test, and documentation

\section{RESULT AND DISCUSSION}

The cognitive learning outcomes data on the first cycle gotten from the result of the test that given in the end of the first cycle and students need to pass the minimum completeness criteria. The cognitive learning outcomes of the students in the first cycle could be seen in the table below:

Table 1. cognitive learning outcomes

\begin{tabular}{|c|c|c|c|}
\hline Grade & Category & Frequency & percentage \\
\hline $\begin{array}{c}\text { Grade }> \\
8.4\end{array}$ & Pass & 11 & $85 \%$ \\
\hline $\begin{array}{c}\text { Grade } \\
8.5\end{array}$ & Fail & 2 & $15 \%$ \\
\hline $\begin{array}{c}\text { Total } \\
\text { Students }\end{array}$ & 13 & $100 \%$ \\
\hline $\begin{array}{c}\text { Total } \\
\text { Grades }\end{array}$ & & 120 \\
\hline $\begin{array}{c}\text { Average } \\
\text { Grades }\end{array}$ & & 9.23 \\
\hline
\end{tabular}




\section{Application Of Math Review Game to Increase Cognitive Learning Outcomes And Students Involvement Level In Mathematic Lesson- Di Ohanes Richi Christian Plenden, Gamaliel Septian Airlanda}

From the table could be seen the cognitive result of the students, 11 students categorized pass the minimum completeness criteria and 2 students categorized not pass the minimum completeness criteria. The cognitive learning outcomes data on the second cycle gotten from the test that given in the end of the second cycle and students need to pass the minimum completeness criteria. The cognitive learning outcomes of the students in the first cycle could be seen in the table below:

Table 2. The cognitive learning outcomes of the students in the first cycle

\begin{tabular}{|l|l|l|l|}
\hline Grade & Category & Frequency & percentage \\
\hline Grade $>8.4$ & Pass & 13 & $100 \%$ \\
\hline Grade $<8.5$ & Fail & 0 & $0 \%$ \\
\hline Total Students & 13 & $100 \%$ \\
\hline Total Grades & 127 & \\
\hline $\begin{array}{l}\text { Average } \\
\text { Grades }\end{array}$ & 9.73 & \\
\hline
\end{tabular}

From the table could be seen the cognitive result of the students, all 13 students categorized pass the minimum completeness criteria. Based on this data, known that there is enhancement in the cognitive learning outcomes of the students in the second cycle rather than first cycle. Students involvement level result in the first cycle obtained from observation, student and teacher observation sheet, and student involvement questionnaire. The result is written in down below:

Table 3. The result

Annotation

\begin{tabular}{|c|c|c|c|c|}
\hline Number & Interval & Category & Frequency & Precentage \\
\hline 1 & $\mathrm{~N}>=75$ & Active & 7 & $54 \%$ \\
\hline 2 & $50<\mathrm{N}<75$ & Enough & 5 & $38 \%$ \\
\hline 3 & $25<\mathrm{N}<50$ & Less Active & 1 & $8 \%$ \\
\hline 4 & $\mathrm{~N}<25$ & Passive & 0 & $0 \%$ \\
\hline \multicolumn{3}{|c|}{ SUM } & 13 & $100 \%$ \\
\hline \multicolumn{3}{|c|}{ Highest Grade } & \multicolumn{2}{|c|}{90} \\
\hline \multicolumn{3}{|c|}{ Lowest Grade } & \multicolumn{2}{|c|}{57.5} \\
\hline \multicolumn{3}{|c|}{ Total Students' Involvement Level } & \multicolumn{2}{|c|}{990} \\
\hline \multicolumn{3}{|c|}{ Average } & \multicolumn{2}{|c|}{76} \\
\hline \multicolumn{3}{|c|}{$\mathrm{P}$} & \multicolumn{2}{|c|}{$54 \%$} \\
\hline \multicolumn{3}{|c|}{ Category } & \multicolumn{2}{|c|}{ Enough } \\
\hline
\end{tabular}

From the data above, it showed us the student involvement level result on the first cycle. There are 7 students which is active with percentage $54 \%, 5$ students which is enough with percentage $38 \%$, and 1 student less active with percentage $8 \%$. The highest student involvement level grade from this cycle is 90 out of 100 and the lowest student involvement level score from this cycle is 57.5 out of 100 . The total involvement level grade of all students is 990 with average score 76 and this could categorize as enough.

Student involvement result in the second cycle also obtained from observation, student and teacher observation, and student involvement level questionnaire. The result is written down below :

Table 4. Student involvement result in the second cycle

\begin{tabular}{|c|c|c|c|c|}
\hline \multicolumn{5}{|c|}{ Annotation } \\
\hline Number & Interval & Category & Frequency & Precentage \\
\hline 1 & $\mathrm{~N}>=75$ & Active & 10 & $77 \%$ \\
\hline 2 & $50<\mathrm{N}<75$ & Enough & 3 & $23 \%$ \\
\hline 3 & $25<\mathrm{N}<50$ & $\begin{array}{c}\text { Less } \\
\text { Active }\end{array}$ & 0 & $0 \%$ \\
\hline 4 & $\mathrm{~N}<25$ & Passive & 0 & $0 \%$ \\
\hline \multicolumn{3}{|c|}{ SUM } & 13 & $100 \%$ \\
\hline \multicolumn{3}{|c|}{ Highest Grade } & \multicolumn{2}{|c|}{95} \\
\hline \multicolumn{3}{|c|}{ Lowest Grade } & \multicolumn{2}{|c|}{57.5} \\
\hline \multicolumn{3}{|c|}{$\begin{array}{c}\text { Total Students' Involvement } \\
\text { Level }\end{array}$} & \multicolumn{2}{|c|}{1030} \\
\hline \multicolumn{3}{|c|}{ Average } & \multicolumn{2}{|c|}{79} \\
\hline \multicolumn{3}{|c|}{$\mathrm{P}$} & \multicolumn{2}{|c|}{$77 \%$} \\
\hline \multicolumn{3}{|c|}{ Category } & \multicolumn{2}{|c|}{ Active } \\
\hline
\end{tabular}

From the data above, it showed us that the student involvement level result on the second cycle. There are 10 active students with percentage $77 \%$ and 3 students categorized as enough active with percentage $23 \%$. The highest student involvement level grade from this cycle is 95 out of 100 and the lowest student's involvement level grade from this cycle is 57.5 out of 100 . The total involvement level grade of all students is 1030 
with average grade 79 and this could categorize as active.

Analysis Data Result of Cognitive Learning Outcomes from the first cycle and second cycle have increased. This is the recapitulation of the cognitive learning outcomes data of the 5th grade Mountainview Christian Elementary School from the first and second cycle:

Table 5. Analysis Data Result of Cognitive Learning Outcomes from the first cycle and second cycle have increased

\begin{tabular}{|c|c|c|}
\hline Criteria & $\begin{array}{c}\text { 1st } \\
\text { cycle }\end{array}$ & $\begin{array}{c}\text { 2nd } \\
\text { cycle }\end{array}$ \\
\hline Pass & $85 \%$ & $100 \%$ \\
\hline Not Pass & $15 \%$ & $0 \%$ \\
\hline Total Grades & 120 & 127 \\
\hline $\begin{array}{c}\text { Average } \\
\text { Grades }\end{array}$ & 9.23 & 9.73 \\
\hline
\end{tabular}

Based on the table could be seen that the average grades from the first cycle and second cycle have increased. The average grade in the first cycle is 9.23 and increased become 9.73. Percentage the total amount of the students that pass the minimum completeness criteria also increased in the second cycle. In the first cycle, students that pass the minimum completeness criteria is $85 \%$ and increased into $100 \%$ in the second cycle. Percentage of each students grade also mostly increased in the second cycle.

Involvement Level from the first and second cycle have increased. The Analysis Data Result of Student Involvement Level first and second cycle written in the table below:

Table 6. Involvement Level from the first and second cycle have increased.

\begin{tabular}{|c|c|c|}
\hline Criteria & 1st Cycle & $\begin{array}{c}\text { 2nd } \\
\text { Cycle }\end{array}$ \\
\hline Highest Grade & 90 & 95 \\
\hline Lowest Grade & 57.5 & 57.5 \\
\hline $\begin{array}{c}\text { Total Students' } \\
\text { Involvement Level }\end{array}$ & 990 & 1030 \\
\hline Average & 76 & 79 \\
\hline Category & Enough & Active \\
\hline
\end{tabular}

Based on the table, comparing first cycle and second cycle the grade of the students are increased. In the first cycle, the total grade is 990 and the average is 76 categorized as enough. In the other hand, the total score of second cycle is 1030 with average is 79 categorized as active. In the first cycle shown the average is 76 become 79 in the second cycle, from enough become active. From the table could be concluded that there is enhancement of student involvement in every cycle.

Also, there are increasing student's involvement level in each student. Most of students have increase their involvement level, but also there are some of them that decrease in the second cycle because they have difficulties with language and need more times to understand, and some of them play on their own that's why they didn't more active in the second cycle.

\section{CONCLUSION}

Based on the classroom action research that be done to the fifth grade Mountainview Christian Elementary School Salatiga in the first quarter of 2019/2020, using Math Review Game Method could increase the cognitive learning outcomes and involvement level of the student. By applying Math Review Game, student could learn and got review of the lesson through playing game. It made the students become more active and enjoy the lesson, they become more active and participating in every lesson because the game caught their interest. This is proven by the result of the research which student involvement level increased. The involvement level average grade is 30 categorized as active and increased in the second cycle become 32 categorized as very active. By using Math Review Game the cognitive level also increased from the first cycle, the average grade is 9.23 with percentage $85 \%$ 
2124 Application Of Math Review Game to Increase Cognitive Learning Outcomes And Students Involvement Level In Mathematic Lesson- Di Ohanes Richi Christian Plenden, Gamaliel Septian Airlanda

students that pass the minimum completeness criteria with information 11 students pass the minimum completeness criteria and 2 students not pass minimum completeness criteria increased in the second cycle, the average grade is 9.73 with percentage $100 \%$ students pass the minimum completeness criteria with information all students pass the minimum completeness criteria. Through the result of this research could be proven that Classroom Action Research through Math Review Game could increasing the cognitive learning outcomes and student involvement level of fifth grade students Mountainview Christian Elementary School in the first quarter of year $2019 / 2020$

\section{RERERENCES}

Bloom, B. (1956). Taxonomy of Educational Objectives: The Classification of Education Goals: Handbook I, cognitive domain. New York: Toronto: Longmans, Green.

Csikszentmihalyi, M. (1990). Flow-The Phsycology of Optimal Experience. New York: Harper Perennial.

Darmansyah. (2010). Strategi Pembelajaran Menyenangkan dengan Humor. Jakarta: PT Bumi Aksara.

DePorter, B., Mark Reardon, \& Sarah SingerNourie. (2001). Quantum Teaching: Mempraktikkan Quantum Learning di Ruang-ruang Kelas. Edisi Terjemahan oleh Ary Nilandari. Cetakan IV. Bandung : Kaifa.

Dryden, G., \& Vos, D. (1999). The Learning Revolution. New Zealand: The Learning Web.

Johnson, D., Johnson, R., \& Smith, K. (1991). Active Learning: Cooperation in The College Classroom. Edina: MN: Interaction Book Company.

KEMDIKBUD. (2013, Februari 20). Konsep dan Implementasi Kurikulum 2013. Retrieved from https://www.kemdikbud.go.id /: https://www.kemdikbud.go.id /kemdikbud/dokumen/paparan/paparan\%2 OWamendik.pdf

Kline, P. (1823). The Everyday Genius. North Lincoln Street, Airlington: Great Ocean Inc.

Kunandar. (2012). Langkah Mudah Penelitian Tindakan Kelas. Jakarta: PT Rajagrafindo Persada.

Mc Clintock, C. (1982). Problem Solving: Some Means and Some Ends. In P. o. Association, Problem Solving in the Mathematic Classroom (p. 9). ATA.

Silver, H., Brunsting, J., \& Walsh, T. (2012). Math Tools, Grades 3-12: 60+ Ways to Build Mathematical Practices, Differentiate Instruction, and Increase . California: Corwin Press. 